Article

\title{
Tungsten-Doped Zinc Oxide and Indium-Zinc Oxide Films as High-Performance Electron-Transport Layers in N-I-P Perovskite Solar Cells
}

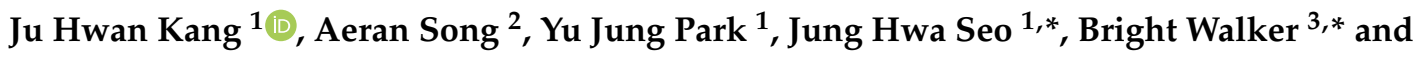 \\ Kwun-Bum Chung ${ }^{2, *}$ \\ 1 Department of Materials Physics, Dong-A University, Busan 49315, Korea; \\ kangjuhwan89@gmail.com (J.H.K.); j6768kr@gmail.com (Y.J.P.) \\ 2 Division of Physics and Semiconductor Science, Dongguk University, Seoul 04620, Korea; \\ aeransong@dongguk.edu \\ 3 Department of Chemistry, Kyung Hee University, Seoul 02447, Korea \\ * Correspondence: seojh@dau.ac.kr (J.H.S.); walker@khu.ac.kr (B.W.); kbchung@dongguk.edu (K.-B.C.); \\ Tel.: +82-51-200-7233 (J.H.S.)
}

Received: 18 February 2020; Accepted: 24 March 2020; Published: 26 March 2020

\begin{abstract}
Perovskite solar cells (PSCs) have attracted tremendous research attention due to their potential as a next-generation photovoltaic cell. Transition metal oxides in N-I-P structures have been widely used as electron-transporting materials but the need for a high-temperature sintering step is incompatible with flexible substrate materials and perovskite materials which cannot withstand elevated temperatures. In this work, novel metal oxides prepared by sputtering deposition were investigated as electron-transport layers in planar PSCs with the N-I-P structure. The incorporation of tungsten in the oxide layer led to a power conversion efficiency (PCE) increase from 8.23\% to $16.05 \%$ due to the enhanced electron transfer and reduced back-recombination. Scanning electron microscope (SEM) images reveal that relatively large grain sizes in the perovskite phase with small grain boundaries were formed when the perovskite was deposited on tungsten-doped films. This study demonstrates that novel metal oxides can be used as in perovskite devices as electron transfer layers to improve the efficiency.
\end{abstract}

Keywords: transparent metal oxide; perovskite solar cell; tungsten-doped InZnO; zinc-oxynitride

\section{Introduction}

Organic-inorganic perovskite solar cells (PSCs) are viewed as promising next-generation optoelectronic devices due to their superior optical and electrical properties, simple solution handling and low cost [1-5]. In particular, the power conversion efficiency (PCE) of PSCs has increased to more than $20 \%$ over the past decade [6,7]. Organic-inorganic hybrid lead halide perovskites possess excellent properties for solar cell applications, such as strong light harvesting ability (absorption coefficients, $\alpha$, of more $\left.5 \times 10^{4} \mathrm{~cm}^{-1}\right)$, high carrier mobility $\left(0.1-10 \mathrm{~cm}^{2} \cdot \mathrm{V}^{-1} \cdot \mathrm{s}^{-1}\right)$ and long diffusion lengths $(0.1-1.5 \mu \mathrm{m})$ [8-11]. The PCE of PSCs has improved rapidly due to the development of techniques to control film morphology, effective device architectures, interface engineering, and a constantly growing knowledge base of techniques to control and optimize electronic band structures and semiconducting properties. The most commonly used device architecture comprises a N-I-P structure using a sintered $\left(>450{ }^{\circ} \mathrm{C}\right)$ mesoporous $\mathrm{TiO}_{2}\left(\mathrm{mp}-\mathrm{TiO}_{2}\right)$ layer as the electron-transport layer (ETL)-yielding PCEs of up to 22.1\% [12,13]. However, high-temperature processes are not favorable for device fabrication and hinder the development of flexible modules [14]. To overcome these obstacles, researchers have focused on planar devices using low-temperature solution-treated transport 
layers. Currently, the most commonly used oxides include $\mathrm{TiO}_{2}[2,15], \mathrm{ZnO}$ [16] although a variety of other metal oxides [17,18], such as $\mathrm{Nb}_{2} \mathrm{O}_{5}[19]$ and $\mathrm{SnO}_{2}[20,21]$, may also be used, allowing some control of the interfacial properties and variability in junctions formed between electrodes and the $\mathrm{CH}_{3} \mathrm{NH}_{3} \mathrm{PbI}_{3}$ layer. Recently, reports of new metal oxide-based PSCs have demonstrated that PCEs in the range of $15 \sim 20 \%$ are possible via development and optimization of new oxide layers [22-30]. These inorganic oxides are considered excellent interfacial materials due to their superior stability and electrical properties. These interfacial metal oxide layers generally facilitate the extraction of n-type charge carriers from the active layer and act as effective cathode interlayers. Although $\mathrm{TiO}_{2}$ and $\mathrm{ZnO}$ themselves are fairly well understood [31,32], there are a wide variety of other metal oxides and mixtures which may be used as ETLs in PSCs, which are not well optimized. The composition of metal oxide semiconductors can be used to control the electrical characteristics and additionally, for metal oxide films deposited under a partial vacuum, the oxygen partial pressure in the deposition process can be used to control the composition and properties of films [33-35]. Zinc-oxynitride ( $\mathrm{ZnON}$ ) [36,37], Zinc oxide (ZnO) [38,39], Indium-zinc oxide (IZO) [40,41], and W-doped indium-zinc oxide (WIZO) [42,43], for example, are metal oxide semiconductors which have been investigated as channel materials for thin-film field-effect transistors in display backplanes and other optoelectronic devices due to their high transparency, high mobility, and high conductivity. Notably, the element $\mathrm{W}$ in WIZO thin films can be used to control the electronic structure, including the band alignment, oxygen-deficient bonding states, and band edge states below the conduction band. In addition, the $\mathrm{W}$ doping concentration in WIZO thin films may affect the electronic structure and can be used to control the device performance and stability characteristics [44]. Although W-based oxide films have yielded PCEs of up to $13 \%$, they have received considerably less attention than other oxides such as $\mathrm{Zn}, \mathrm{Sn}$, In and Ni $[28,41,44]$. In this work, we report the fabrication of high-efficiency PSCs based on the architecture: ITO/metal oxide/ $\mathrm{PC}_{61} \mathrm{BM} / \mathrm{CH}_{3} \mathrm{NH}_{3} \mathrm{PbI}_{3} / \mathrm{Spiro}-\mathrm{OMeTAD} / \mathrm{MoO}_{3} / \mathrm{Ag}$. In this configuration, metal oxides are deposited by sputtering as an ETLs and are additionally modified by including an n-type, organic $\mathrm{PC}_{61} \mathrm{BM}$ layer as an electron extraction layer (EEL) [45-52], which improves wettability of the perovskite solution on the substrate and passivates the oxide surface for perovskite, reducing the density of the trapped states [53-55]. The WIZO film exhibited the lowest conduction band and improved open-circuit voltage $\left(\mathrm{V}_{\mathrm{OC}}\right)$ compared to other metal oxide films. Moreover, the WIZO film enhanced the crystallinity of the perovskite film and remarkably reduced leakage current in the PSCs. The optimized PSC showed different grain sizes in SEM images compared to other metal oxide films. In addition, the encapsulated PSCs with the WIZO film showed excellent long-term stability under ambient operating conditions. The N-I-P device structures fabricated with metal oxide ETLs produced PCEs of up to $16.44 \%$. To the best of our knowledge, this constitutes the highest performance yet reported for devices based on $\mathrm{W}$ oxides and demonstrates the great potential of this new material as ETLs for PSCs and for other potential applications [42,43].

\section{Experimental Section}

\subsection{Fabrication Process of the $\mathrm{ZnON}$ and WIZO Films}

Pre-patterned ITO substrates $(1.5 \times 1.5 \mathrm{~cm}, 7 \Omega / \mathrm{sq})$ were immersed in deionized water (DI Water), acetone, isopropanol solution (IPA) and ultra-sonication for $20 \mathrm{~min}$ in each solvent. The washed ITO substrates were stored in an oven at $80^{\circ} \mathrm{C}$ and treated with ozone using a UV-ozone cleaner immediately prior to use. $20 \mathrm{~nm}$ thick $\mathrm{ZnON}$ films were next deposited by reactive magnetron sputtering using a 3" diameter $\mathrm{Zn}$ target with a purity of $99.99 \%$ in a reactive gas $\left(\mathrm{Ar} / \mathrm{N}_{2} / \mathrm{O}_{2}\right)$ without substrate heating [56]. The gas delivery system used precision mass flow controllers to control the flow rate of each gas. Sputtering used a direct current (DC) power of $100 \mathrm{~W}$ and a working pressure of 5 mTorr. As-deposited $\mathrm{ZnON}$ thin films were post-processed by thermal annealing at $300^{\circ} \mathrm{C}$ for $1 \mathrm{~h}$ in an ambient air. WIZO films (20 nm thick) were deposited onto ITO films via the co-sputtering of a $\mathrm{WO}_{3}$ and IZO (1:1 at. \%) sputtering target using a radio-frequency (RF) sputtering system without 
substrate heating [57]. The processes pressure was set at $5 \mathrm{mTorr}$ and the relative oxygen flow rate $\mathrm{O}_{2} /\left(\mathrm{Ar}+\mathrm{O}_{2}\right)$ ratio was 0.05 . To change the $\mathrm{W}$ doping concentration in the WIZO films, we controlled the deposition rate through the variation of the input $\mathrm{RF}$ power of the $\mathrm{WO}_{3}$ target from 5 to $20 \mathrm{~W}$ while fixing that of the IZO target at $150 \mathrm{~W}$. WIZO thin films were post-processed by thermal annealing at $250{ }^{\circ} \mathrm{C}$ for $1 \mathrm{~h}$ in an air atmosphere.

\subsection{Device Fabrication}

All samples subsequently were brought into the $\mathrm{N}_{2}$ glove-box for the spin coating of $\mathrm{PC}_{61} \mathrm{BM}$, which was spin-cast at $2000 \mathrm{rpm}$ for $30 \mathrm{~s}$ followed by annealing at $80^{\circ} \mathrm{C}$ for $10 \mathrm{~min}$ (Chemin St-François, Dorval, Canada). A 2.5 wt.\% solution of $\mathrm{PC}_{61} \mathrm{BM}$ in chloroform/chlorobenzene (CB) (1:1 volume ratio) was used. $1.1 \mathrm{M}$ solutions of $\mathrm{PbI}_{2}$ (99.99\%, Sigma Aldrich, Merck KGaA, Darmstadt, Germany) and methylammonium iodide (Sigma Aldrich, 99.5\%) were dissolved in a mixed DMF and DMSO solvent $(7: 3 \mathrm{ratio})$ with stirring at $60^{\circ} \mathrm{C}$ for $60 \mathrm{~min}$. After that, the solution was deposited via a solvent engineering method by spin coating the perovskite precursor solution at $3500 \mathrm{rpm}$ for $30 \mathrm{sec}$ and at $6500 \mathrm{rpm}$ for $5 \mathrm{sec}$, respectively. Anhydrous chlorobenzene $(45 \mu \mathrm{L})$ was dripped at the center of the substrate in the second step as the prepared film was put onto the hot plate at $100{ }^{\circ} \mathrm{C}$ for $10 \mathrm{~min}$ under $\mathrm{N}_{2}$ atmosphere. The hole transfer layer was prepared by spin coating a solution consisting of $80 \mathrm{mg}$ of spiro-OMeTAD $8.4 \mu \mathrm{l}$ of 4-tert-butylpyridine, and $51.6 \mu \mathrm{l}$ of bis (trifluoromethane) sulfonamide lithium salt (Li-TFSI) solution $(154 \mathrm{mg} / \mathrm{mL}$ in acetonitrile) all dissolved in $1 \mathrm{~mL} \mathrm{CB}$ for $30 \mathrm{sec}$ at $4000 \mathrm{rpm}$. The spiro-OMeTAD layer was aged overnight in the dark under an atmosphere of dry air to promote oxidation and doping. Finally, $\mathrm{MoO}_{3}(5 \mathrm{~nm})$ and $\mathrm{Ag}(100 \mathrm{~nm})$ contacts were thermally evaporated onto the spiro-OMeTAD.

\subsection{Characterization}

Current density-voltage (J-V) measurements were collected using a Keithley 2400 source measure unit inside a nitrogen filled glove-box using a high-quality optical fiber to guide the light from a xenon arc lamp to the solar cell devices. The solar cell devices were illuminated with a light intensity of $100 \mathrm{~mW} / \mathrm{cm}^{2}$ calibrated using a standard silicon reference cell immediately prior to testing. External quantum efficiency (EQE) measurements were carried out using a QEX7 system manufactured by PV Measurements, Inc (Point Roberts, WA, USA). Atomic force microscopy (AFM) images were obtained using a Veeco Multimode microscope operating in tapping mode. X-ray diffraction (XRD) patterns were collected using a Bruker AXS D8 advance diffractometer (Bruker AXS, Karlsruhe, Germany). UV-vis spectra were taken using and Agilent Cary 5000 UV-vis spectrometer. Ultraviolet photoelectron spectroscopy (UPS) spectra were obtained using a Thermo Fischer Scientific ESCALB 250XI (Waltham, MA, USA).

\section{Results}

The device structure used in this study is shown in Figure 1a. In this configuration, a thin metal oxide film was first deposited on ITO glass by sputtering, followed by a light harvesting $\mathrm{PC}_{61} \mathrm{BM} / \mathrm{CH}_{3} \mathrm{NH}_{3} \mathrm{PbI}_{3}$ junction [58,59], which was deposited by spin coating. Additional details concerning experimental methods are included in the Supplementary Information. Figure $1 \mathrm{~b}$ shows the energy alignment in the PSCs; in this system photogenerated electrons migrate to the $\mathrm{PC}_{61} \mathrm{BM}$, and are transported through the metal oxide films before being collected at the ITO cathode. Photogenerated holes migrate to the spiro-OMeTAD/ $\mathrm{MoO}_{3}$ layers and are collected by the $\mathrm{Ag}$ anode $[60,61]$. The band energies of each material were taken from the literature, except for those of metal oxides. The valence band energies of the metal oxides were obtained by UPS and the conduction band energies were obtained by adding the reported optical bandgap of each material to their valence band energies (Figure S1, Supporting Information) [62]. According to a previously reported transistor, WIZO mobility and energy levels are $19.57 \mathrm{~cm}^{2} / \mathrm{Vs}$ and $3.4 \mathrm{Ev}$ [44]. The Schottky barrier of ITO and $\mathrm{PC}_{61} \mathrm{BM}$ is $0.8 \mathrm{eV}$ when metal oxides are not used. This energetic barrier is expected to limit 
electron extraction efficiency and promote electron-hole recombination [63]. This indicates that the performance of PSCs may be improved by reducing the recombination of electrons and holes by creating an Ohmic contact using a metal oxide to reduce the energy barrier between the conduction band of the semiconductor and the cathode. In terms of energy levels, WIZO possesses a smaller barrier to electron extraction, indicating that electron extraction should be higher than other metal oxide films by making an Ohmic contact with $\mathrm{PC}_{61} \mathrm{BM}$. To probe the effect of metal oxides on device performance, PSCs with and without ETLs were fabricated as described in the experimental section. Figure 2a shows the J-V curves for these cells. The corresponding photovoltaic parameters of the PSC performance are given in Table 1. Devices without ETLs yielded a $\mathrm{V}_{\mathrm{OC}}$ of $1.00 \mathrm{~V}$, a short circuit current density (JSC) of $18.20 \mathrm{~mA} / \mathrm{cm}^{2}$ and a fill factor (FF) of $54.7 \%$, corresponding to a PCE of $9.95 \%$. The $\mathrm{V}_{\mathrm{OC}}$ was relatively high, but the $\mathrm{J}_{\mathrm{SC}}$ and FF were very low, which can be attributed to inefficient electron extraction arising from the Schottky barrier at the ITO/PC ${ }_{61} \mathrm{BM}$ interface. The poor $\mathrm{FF}$ in particular leads to a low efficiency. When $\mathrm{ZnON}$ was used as an ETL, the devices exhibited an even lower PCE of $8.9 \%$ with a $\mathrm{V}_{\mathrm{OC}}$ of $0.95 \mathrm{~V}$, a J $\mathrm{J}_{\mathrm{SC}}$ of $19.06 \mathrm{~mA} / \mathrm{cm}^{2}$ and an FF of 48.7. This can be attributed to the large conduction band offset between $\mathrm{ZnON}$ and $\mathrm{PC}_{61} \mathrm{BM}$ layer (Figure S1, Supporting Information), together with the low grain size and high surface roughness of $\mathrm{ZnON}$ layer (Figures 3 and 4). Therefore, despite having a high electron mobility, the $\mathrm{ZnON}$ layer was not able to improve the charge transport, and instead caused increased contact resistance. Replacing $\mathrm{ZnON}$ with $\mathrm{ZnO}$ led to a significant enhancement in device efficiency. The device with $\mathrm{ZnO}$ yielded a PCE of $11.31 \%$ with a J $\mathrm{J}_{\mathrm{SC}}$ of $20.09 \mathrm{~mA} / \mathrm{cm}^{2}$, a $\mathrm{V}_{\mathrm{OC}}$ of $1.02 \mathrm{~V}$ and an FF of $54.8 \%$. Among the oxides tested, however, devices with IZO and WIZO layers showed the best performance. PSCs based on WIZO yielded a JSC of $21.28 \mathrm{~mA} / \mathrm{cm}^{2}$, a $\mathrm{V}_{\mathrm{OC}}$ of $1.10 \mathrm{~V}$, an FF of $70.0 \%$ and a PCE of $16.44 \%$. Among the different metal oxides, WIZO yielded the best performance by a significant margin.

(a)

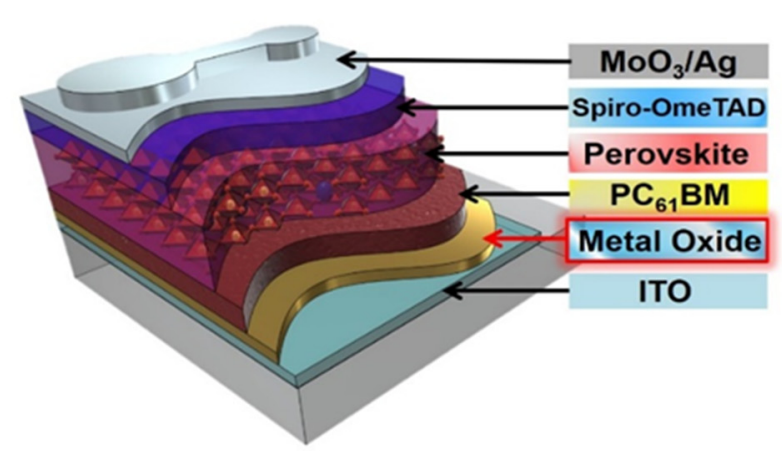

(b)

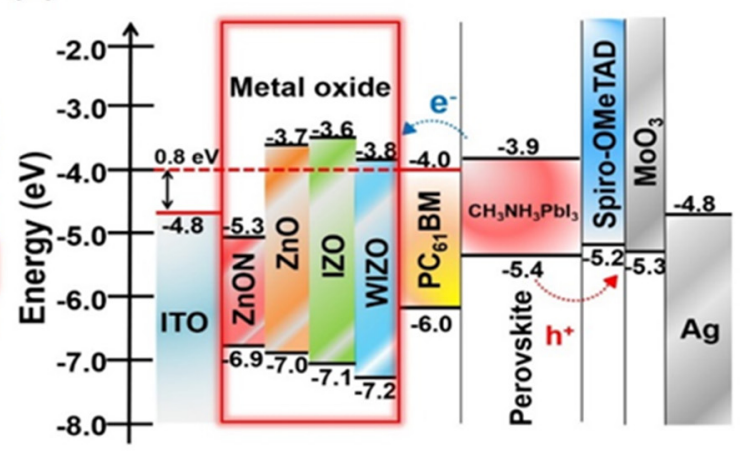

Figure 1. Schematic diagrams. (a) Device architecture of N-I-P perovskite cells with various metal oxide layers and (b) corresponding energy band diagram (all energies are relative to the vacuum level).

IZO devices show a higher PCE than other metal oxide devices; however, they are disadvantageous in electron transport due to the large conduction band offsets which promotes the recombination of electrons and holes (Figure S1). The $\mathrm{V}_{\mathrm{OC}}$ in a solar cell is governed by many factors; however, the presence of non-radiative recombination pathways for electrons and holes is thought to be one of the primary loss mechanism which reduces the $\mathrm{V}_{\mathrm{OC}}$ to less than theoretical values in PSCs, and this most likely originates from the presence of defect sites which cause carrier trapping and trap assisted recombination [63]. Additionally, any imperfections in solar cells fabrication which introduce shunting paths will also act to reduce the $\mathrm{V}_{\mathrm{OC}}$ by increasing the dark leakage current [63-65]. The average FFs obtained with four different ETLs are $48.7 \%, 54.8 \%, 61.5 \%$ and $70.0 \%$, respectively, with the $\mathrm{W}$-doped film showing a significant advantage compared to the other oxide films. The $J-V$ characteristics of the devices collected in the dark are presented in Figure $2 \mathrm{~b}$ and the device area-normalized data are plotted on a logarithmic scale. In general, smaller series resistance 
$\left(R_{\mathrm{S}}\right)$ and larger shunt resistance $\left(\mathrm{R}_{\mathrm{SH}}\right)$ will result in larger FF. Here, the increase in FF is due to both a decrease in $R_{S}$ and an increase of $R_{S H}$, which may arise from better contact between perovskite film and metal oxide/ $\mathrm{PC}_{61} \mathrm{BM}$ film, higher perovskite film coverage, and better hole-blocking abilities after with ETLs [66,67].

In Figure 2c, the EQE spectra for all devices show similar spectral features, consistent with the identical active layers used in each device. The EQE of the devices without metal oxides and or with $\mathrm{ZnON}$ films showed similar spectral profiles due to the low optical density of these materials in the visible spectrum. Although devices without metal oxides have similar optical properties as the metal oxide devices, the relatively low efficiency in this condition is consistent with the lower built-in potential across the perovskite layer and low carrier extraction efficiency. Additionally, metal oxides possess very deep valence band energies which block the back-diffusion of holes, a process which leads to carrier recombination at the cathode in devices without metal oxide interlayers.

Table 1. Device parameters of the PVSCs based on metal oxide layer.

\begin{tabular}{|c|c|c|c|c|c|c|c|}
\hline \multirow{2}{*}{ Substrates } & \multirow{2}{*}{$\begin{array}{c}\mathrm{V}_{\text {OC }} \\
\text { (V) }\end{array}$} & \multirow{2}{*}{$\frac{\mathrm{JSC}_{\mathrm{SC}}}{\left(\mathrm{mA} \mathrm{cm}{ }^{-2}\right)}$} & \multirow{2}{*}{ FF } & \multirow{2}{*}{$\begin{array}{c}R_{S} \\
\left(\Omega \mathrm{cm}^{2}\right)\end{array}$} & \multirow{2}{*}{$\begin{array}{c}R_{\mathrm{SH}} \\
\left(\Omega \mathrm{cm}^{2}\right)\end{array}$} & \multicolumn{2}{|c|}{ PCE (\%) } \\
\hline & & & & & & Champion & Average \\
\hline No ETL & $1.00 \pm 0.13$ & $18.20 \pm 0.33$ & $0.547 \pm 0.09$ & 14.4 & 173 & 9.955 & $8.98 \pm 0.59$ \\
\hline $\mathrm{ZnON}$ & $0.95 \pm 0.08$ & $19.06 \pm 0.53$ & $0.487 \pm 0.09$ & 18.4 & 244 & 8.90 & $8.23 \pm 0.67$ \\
\hline $\mathrm{ZnO}$ & $1.02 \pm 0.06$ & $20.09 \pm 0.29$ & $0.548 \pm 0.08$ & 15.8 & 354 & 11.31 & $10.94 \pm 0.38$ \\
\hline IZO & $1.07 \pm 0.05$ & $20.78 \pm 0.25$ & $0.615 \pm 0.06$ & 12.4 & 383 & 13.75 & $13.32 \pm 0.35$ \\
\hline WIZO & $1.10 \pm 0.06$ & $21.28 \pm 0.19$ & $0.700 \pm 0.04$ & 7.89 & 602 & 16.44 & $16.05 \pm 0.29$ \\
\hline
\end{tabular}

(a)

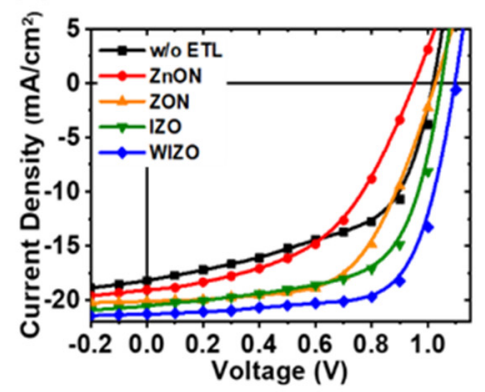

(d)

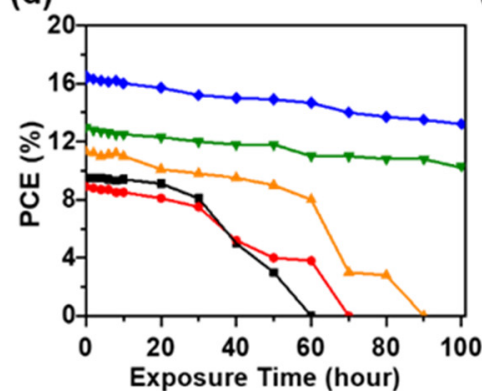

(b)

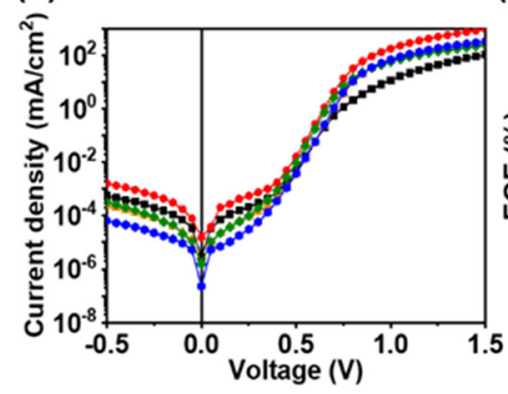

(c)

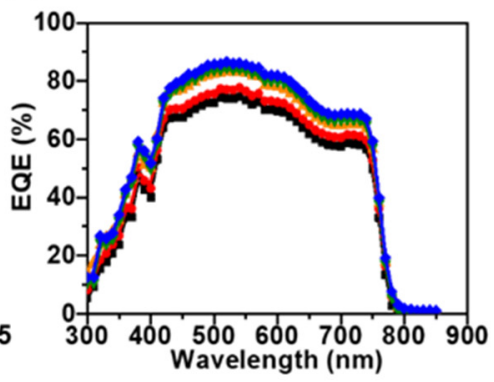

(e)

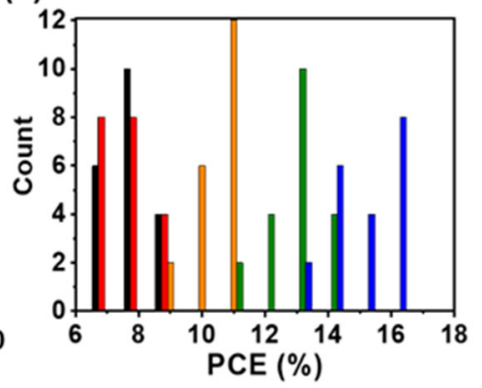

Figure 2. Current Density vs Voltage curves measured (a) under simulated AM1.5G solar light and (b) under dark. (c) EQE spectra, (d) stability properties after exposure in Air and (e) statistics of the performance for all devices corresponding to (a).

Considering the practical application of perovskite solar cells in the future, there is a pressing need for low-cost renewable energy that can potentially be provided by PSCs; however, it is still an enormous challenge to slow down the degradation of sensitive perovskite films under operating conditions $[68,69]$. To evaluate the effect of the different oxide layers on stability, we monitored bare devices without any encapsulation, and measured PSC characteristics daily over the course of 5 days in ambient air. PCE vs storage time data are shown in Figure 2d. Surprisingly, the PCE of the WIZO-based 
device remained at $91.4 \%$ of its original value after $50 \mathrm{~h}$ of storage, and retained over $88.5 \%$ of the original PCE even after 100 hours. Likewise, for IZO-based devices, the PCE remained at $84.7 \%$ even after $100 \mathrm{~h}$. By contrast, the degradation of ITO-based devices (without ETLs) and ZnON accelerated after $30 \mathrm{~h}$, decreasing to $68.4 \%$ PCE after $50 \mathrm{~h}$ storage and reaching $0 \%$ of the original PCE after only $60 \mathrm{~h}$. Meanwhile, devices using $\mathrm{ZnO}$ showed moderate stability, gradually degrading to $0 \%$ of their original PCE over $90 \mathrm{~h}[70,71]$. To confirm the reproducibility of PSCs modified by fullerene ETLs, we fabricated 20 PSC devices for each condition, as shown in Figure 2e and the average PCEs of $8.23 \pm 0.67 \%$ for $(\mathrm{ZnON}), 10.94 \pm 0.38 \%(\mathrm{ZnO}), 13.32 \pm 0.35 \%(\mathrm{IZO}), 16.05 \pm 0.29 \%(\mathrm{WIZO})$ and $8.98 \pm 0.59 \%$ (w/o ETL) were achieved with the metal oxides and w/o ETL, respectively. To further examine the film structures, their relative surface energies were characterized via water contact angle $(\theta)$ (see Figures S6 and S7). ITO surfaces exhibited the lowest contact angles $\left(83^{\circ}\right.$ ), while $\mathrm{ZnON}$ and $\mathrm{ZnO}$ films had similar hydrophilic properties of with contact angles of $88^{\circ}$ and $86^{\circ}$ respectively. Water contact angles of IZO and WIZO films revealed relatively hydrophobic properties with angles of $100^{\circ}$ and $101^{\circ}$ respectively $[67,72]$.

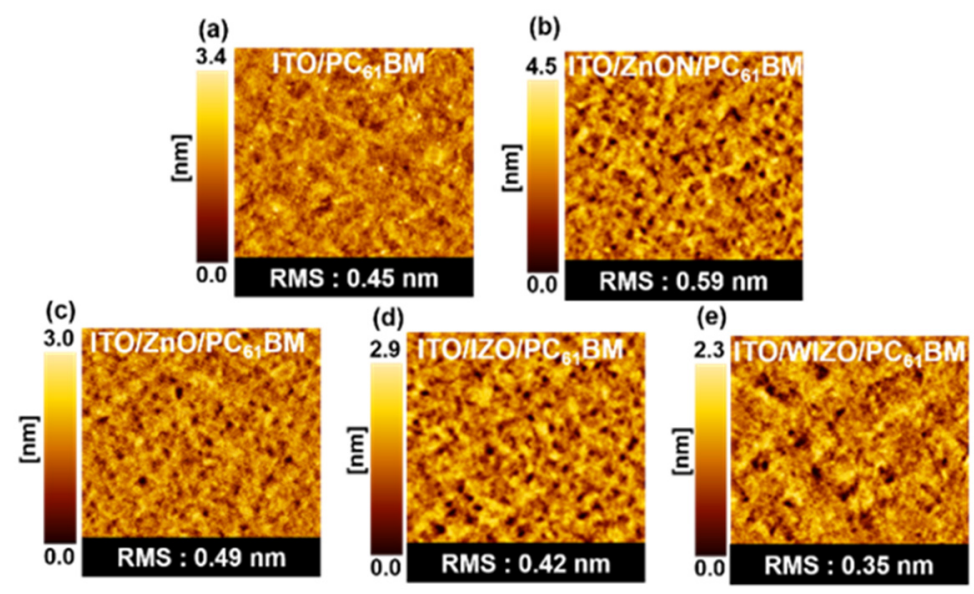

Figure 3. Topographic images (size: $5 \mu \mathrm{m} \times 5 \mu \mathrm{m}$ ) of (a) $\mathrm{ITO} / \mathrm{PC}_{61} \mathrm{BM}$, (b) $\mathrm{ITO} / \mathrm{ZnO} / \mathrm{PC}_{61} \mathrm{BM}$, (c) ITO/ZnON/PC 61 BM, (d) ITO/IZO/PC 61 BM, and (e) ITO/WIZO/PC 61 BM films.

AFM measurements show that the metal oxide films have a smooth and compact morphology (Figure S3), with root mean squared (RMS) roughness values of $3.05 \mathrm{~nm}$ or less. For the interfacial modification of the top surface of the metal oxide layer, $\mathrm{PC}_{61} \mathrm{BM}$ was spin-coated onto the metal oxide film and then annealed at $80^{\circ} \mathrm{C}$ for $5 \mathrm{~min}$. Because the fullerene derivative of $\mathrm{PC}_{61} \mathrm{BM}$ is an excellent electron acceptor with a favorable electronic structure with respect to the perovskite absorber, it is expected that it can effectively modulate the interfacial properties of metal oxide [45]. To understand the structure of $\mathrm{PC}_{61} \mathrm{BM}$ films deposited on metal oxide substrate, the surface morphologies were characterized by AFM (Figure 3) and SEM (Figure S4a-h). After the metal oxide layer was coated with a $\mathrm{PC}_{61} \mathrm{BM}$ layer, the surfaces morphologies exhibited only slight differences. The measured RMS values were $0.45 \mathrm{~nm}$ for substrate with ITO/PC ${ }_{61} \mathrm{BM}, 0.59 \mathrm{~nm}$ for with ITO/ZnON/PC 61 BM, $0.49 \mathrm{~nm}$ for substrate with ITO/ZnO/PC ${ }_{61} \mathrm{BM}, 0.42 \mathrm{~nm}$ for substrate with $\mathrm{ITO} / \mathrm{IZO} / \mathrm{PC}_{61} \mathrm{BM}$, and $0.35 \mathrm{~nm}$ for substrate with ITO/WIZO/PC ${ }_{61} \mathrm{BM}$. AFM shows that after depositing the $\mathrm{PC}_{61} \mathrm{BM}$ layer, the surface of the substrates is decreased relative to ITO. Therefore, we conclude that by combining the water contact angle and surface roughness by AFM indicate that WIZO is best surface for the spin coating of the perovskite. 

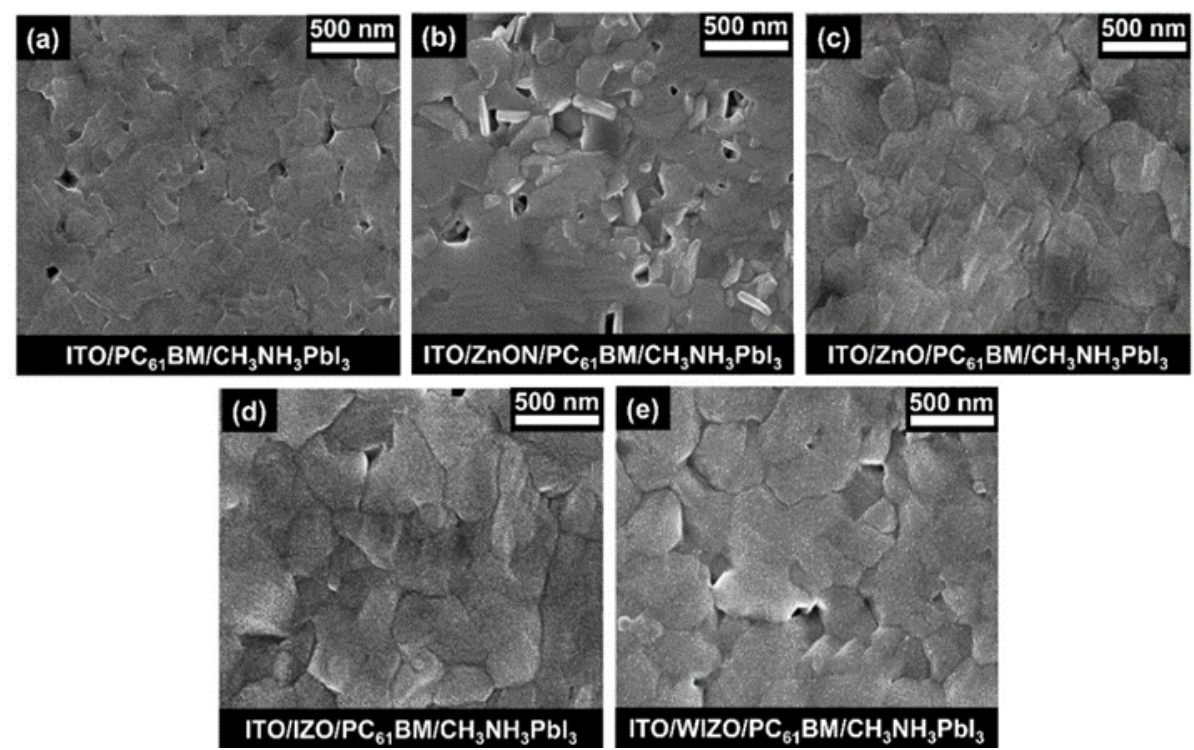

Figure 4. SEM images of $\mathrm{CH}_{3} \mathrm{NH}_{3} \mathrm{PbI}_{3}$ thin films on $\mathrm{PC}_{61} \mathrm{BM}$ prepared on different metal oxides. (a) w/o ETL, (b) ZnON, (c) ZnO, (d) IZO, and (e) WIZO.

Perovskite layers in our devices exhibited large grain sizes and compact morphology, which contributed to the favorable device performance in this study. The rough metal oxide layer became smoother when coated by $\mathrm{PC}_{61} \mathrm{BM}$. To investigate if the grain structure and surface morphologies were affected by the different types of substrates, SEM measurements were further conducted to study the effect of metal oxide on the morphology of $\mathrm{CH}_{3} \mathrm{NH}_{3} \mathrm{PbI}_{3}$ phase. Figure 4 shows the SEM images of $\mathrm{CH}_{3} \mathrm{NH}_{3} \mathrm{PbI}_{3}$ films deposited using $\mathrm{CB}$ as the anti-solvent, after drying and $10 \mathrm{~min}$ annealing at $100^{\circ} \mathrm{C}$. A relatively uniform film with few pinholes was obtained upon depositing $\mathrm{CH}_{3} \mathrm{NH}_{3} \mathrm{PbI}_{3}$ on $\mathrm{PC}_{61} \mathrm{BM}$ without a metal oxide layer (Figure $4 \mathrm{a}$ ). Uneven films with a wide size distribution of round hollows were obtained in the case of perovskite films deposited on substrates with $\mathrm{ZnON}$ films (Figure 4b). Although the control film (w/o ETL) and ZnO films show a uniform and dense form, the grain size is smaller than that of IZO and WIZO films. These results are consistent with the SEM topography images, as shown in Supplementary Figure S2. It has been reported that impurities introduce nucleation sites and induce a heterogeneous nucleation and crystal growth, thus, defects and impurities may lead to smaller crystallites $[60,61]$. Larger grain size indicates lower crystal defect density and trap sites existing in the thin films, which is beneficial for efficient charge transport and reduced charge recombination [73]. As shown in Figure 4c-e, perovskite thin films on substrates with $\mathrm{ZnO}, \mathrm{IZO}$, and WIZO exhibited uniform and compact morphologies, with the average grain size of films deposited on WIZO being the largest, indicating that relatively high-quality perovskite films are formed on these substrates. As AFM and water contact angles clearly show, WIZO was able to influence the overlying perovskite layer, leading to larger grain sizes. To confirm the perovskite grain sizes, additional analysis of XRD data was performed using the Scherrer equation, as shown in Figure S5 and Table S2.

Another possible mechanism by which the oxide films may impact device performance is through their optical properties. Light entering the active layer must first pass through the metal oxide film, thus, light absorbed or reflected by the oxide layer may decrease the amount of light reaching the active layer and consequently decrease the photocurrent. Figure 5 shows the JSC and PCE versus transmittance of substrates with different metal oxides. The photovoltaic performance strongly correlated with the transmittance of the substrates. The average transmittances of the metal oxides were ITO (91.9\%), ZnON (85.0\%), $\mathrm{ZnO}(86.6 \%), \mathrm{IZO}(88.1 \%)$ and WIZO (88.7\%) at the range from 300 to $900 \mathrm{~nm}$, the transmittance of the substrate using $\mathrm{ZnON}$ was the lowest. This decrease in transmittance closely tracked with a decrease in JSC. To fully understand the influence of the oxides' optical properties 
on device performance, optical constants (n and $\boldsymbol{\kappa}$ ) were measured using spectroscopic ellipsometry and used to model the electric field distribution in the devices [74], as shown in Figure S8. Among the four oxides, the $\mathrm{ZnON}$ layer had a slightly higher absorption coefficient $(\kappa)$ and absorbed some incident light before it reached the active layer, resulting in slightly lower field intensity for all layers after $\mathrm{ZnON}$ in this device, explaining the low observed $\mathrm{JSC}_{\mathrm{SC}}$ in this material. Other than this, the $\mathbf{n}$ and $\boldsymbol{\kappa}$ values were similar for all four oxide materials, resulting in otherwise similar electric field distributions through the devices. The high transmittance of our composite electrodes explains the high PCE compared to the reference ITO-based solar cells, since more light is transmitted to the absorbing layer, more charge carriers are generated and extracted [52]. This data reveals that doping is an effective strategy to improve the transmittance of $\mathrm{ZnO}$-based electrodes.

\section{(a)}
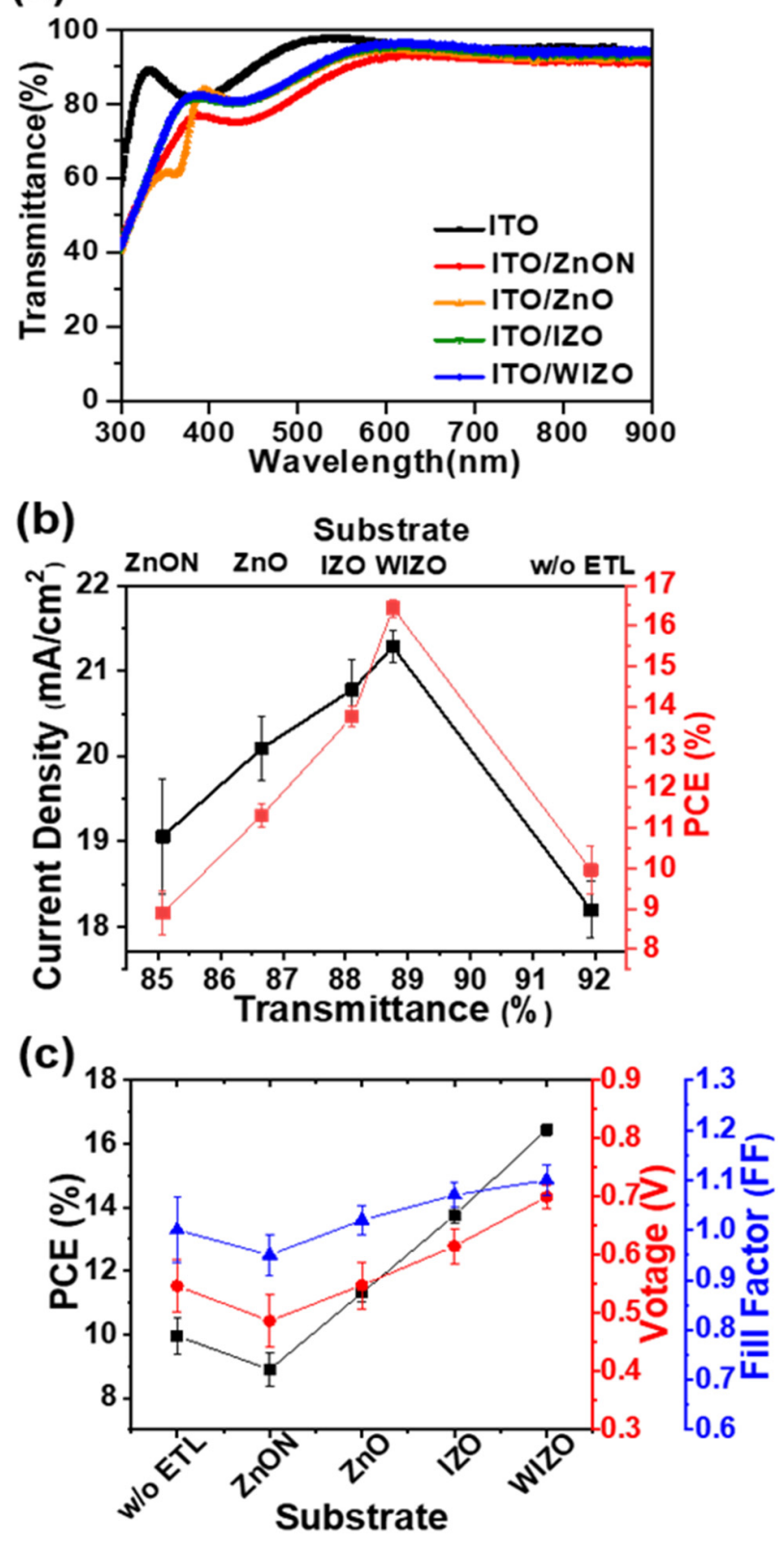

Figure 5. Effect of optical properties on solar cell performance. (a) Optical transmittance of metal oxide films deposited on ITO substrates. (b) Current density and power conversion efficiency versus transmittance, and (c) effect on perovskite PCE, $\mathrm{V}_{\mathrm{OC}}$, and FF in difference metal oxide substrate of PSCs. 


\section{Conclusions}

We have introduced an effective way to improve the performance of N-I-P PSCs with a new series of composite metal oxides as electron-transport layers. These composite electrodes give rise to enhanced injection and extraction of photogenerated electrons, avoiding the accumulation of electrons at the ETL/perovskite interface, which in turn leads to a remarkable increase in $\mathrm{JSC}_{\mathrm{SC}} \mathrm{V}_{\mathrm{OC}}$ and FF, and stability of PSCs. Depending on the metal oxides used, the quality of the perovskite film was also affected. The perovskite grain size correlated with the shape of the underlying film, and when without metal oxide was used, a Schottky barrier was formed between ITO and $\mathrm{PC}_{61} \mathrm{BM}$, so that Ohmic contact was induced using a layer of metal oxide, which is an electron transfer layer. Therefore, it was found that the metal oxide films were found to affect charge transport and charge recombination in the active layer as well. Among the metal oxides investigated in this study, the WIZO metal oxide ETL composition was found to produce optimal results, yielding highly efficient planar PSCs with PCEs of up to $16.44 \%$. The WIZO devices were observed to have the greatest stability and highest PCE of the four new metal oxides. This study demonstrates that sputtered composite metal oxides constitute a functional interface material that can replace existing ETLs, offering significant degree of control over photovoltaic performance and device stability.

Supplementary Materials: The following are available online at http://www.mdpi.com/2073-4360/12/4/737/s1, Figure S1. UPS spectra of (a) the secondary edge region and (b) the valence band region of metal oxide films on ITO substrate, Figure S2. Grain size distribution of the perovskite thin films produced with different metal oxides, Table S1. Grain size distribution of perovskite thin films with different metal oxides, Figure S3. Topographic images (size: $5 \mu \mathrm{m} \times 5 \mu \mathrm{m}$ ) of (a) ITO, (b) ITO/ZnON (c) ITO/ZnO, (d) ITO/IZO, and (e) ITO/WIZO films, Figure S4. Top view SEM images of Top view SEM images of (a) ITO/ZnON thin film, (b) ZnON-sputtered PC $_{61}$ BM layer on ITO substrate, (c) ITO/ZnO, (d) ZnO-sputtered $\mathrm{PC}_{61} \mathrm{BM}$ layer on ITO substrate, (e) ITO/IZO, (f) IZO-sputtered $\mathrm{PC}_{61} \mathrm{BM}$ layer on ITO substrate, (g) ITO/WIZO, and (h) WIZO-sputtered PCBM layer on ITO substrate. Insets are magnified images for each film and scale bar is $50 \mathrm{~nm}$, Figure S5. (a) XRD patterns of $\mathrm{CH}_{3} \mathrm{NH}_{3} \mathrm{PbI}_{3}$ films on different metal oxide/ $\mathrm{PC}_{61} \mathrm{BM}$ substrates. The intensities were normalized with respect to the (110) lattice plane. (b) The zoomed in XRD patterns between 13 and 15 degrees for the MAPbI 3 respectively, Table S2. Measured parameters of $\mathrm{CH}_{3} \mathrm{NH}_{3} \mathrm{PbI}_{3}$ solar cells, Figure $\mathrm{S} 6$. Photos of water droplets on the surfaces of (a) ITO, (b) ITO/ZnON, (c) ITO/ZnO, (d) ITO/IZO, and (e) ITO/W-IZO films deposited on the ITO substrates, Figure S7. Water contact angle images of (a) $\mathrm{PC}_{61} \mathrm{BM}$, (b) $\mathrm{ZnON} / \mathrm{PC}_{61} \mathrm{BM}$, (c) ZnO/PC 61 BM, (d) IZO/PC 61 BM, and (e) WIZO/PC ${ }_{61} \mathrm{BM}$ on the ITO substrate, and Figure S8. Electric field distributions in devices using $\mathrm{ZnO}$, (b) $\mathrm{ZnON}$, (c) IZO, and (d) WIZO ETLs.

Author Contributions: K.-B.C., and J.H.S. designed and initiated the research. J.H.K. and A.S. performed and analyzed the experiments. Y.J.P. conducted AFM measurements. J.H.K., B.W. and J.H.S. wrote the paper. All authors have read and agreed to the published version of the manuscript.

Funding: This research was funded by the National Research Foundation of Korea (NRF) Grant funded by the Ministry of Science and ICT for FirstMover Program for Accelerating Disruptive Technology Development (NRF-2018M3C1B9088457). This research was also supported by the National Research Foundation of Korea (2017R1A2B2012971).

Conflicts of Interest: The authors declare no conflict of interest.

\section{References}

1. Nie, W.; Tsai, H.; Asadpour, R.; Blancon, J.-C.; Neukirch, A.J.; Gupta, G.; Crochet, J.J.; Chhowalla, M.; Tretiak, S.; Alam, M.A. High-efficiency solution-processed perovskite solar cells with millimeter-scale grains. Science 2015, 347, 522-525. [CrossRef]

2. Tan, H.; Jain, A.; Voznyy, O.; Lan, X.; De Arquer, F.P.G.; Fan, J.Z.; Quintero-Bermudez, R.; Yuan, M.; Zhang, B.; Zhao, Y. Efficient and stable solution-processed planar perovskite solar cells via contact passivation. Science 2017, 355, 722-726. [CrossRef] [PubMed]

3. Dong, Q.; Fang, Y.; Shao, Y.; Mulligan, P.; Qiu, J.; Cao, L.; Huang, J. Electron-hole diffusion lengths $>175 \mu \mathrm{m}$ in solution-grown $\mathrm{CH}_{3} \mathrm{NH}_{3} \mathrm{PbI}_{3}$ single crystals. Science 2015, 347, 967-970. [CrossRef] [PubMed]

4. Xie, F.X.; Zhang, D.; Su, H.; Ren, X.; Wong, K.S.; Gratzel, M.; Choy, W.C. Vacuum-assisted thermal annealing of $\mathrm{CH}_{3} \mathrm{NH}_{3} \mathrm{PbI}_{3}$ for highly stable and efficient perovskite solar cells. ACS Nano 2015, 9, 639-646. [CrossRef] [PubMed] 
5. Filip, M.R.; Eperon, G.E.; Snaith, H.J.; Giustino, F. Steric engineering of metal-halide perovskites with tunable optical band gaps. Nat. Commun. 2014, 5, 5757. [CrossRef]

6. Wang, F.; Bai, S.; Tress, W.; Hagfeldt, A.; Gao, F. Defects engineering for high-performance perovskite solar cells. NPJ Flex. Electron. 2018, 2, 22. [CrossRef]

7. Yang, W.S.; Park, B.-W.; Jung, E.H.; Jeon, N.J.; Kim, Y.C.; Lee, D.U.; Shin, S.S.; Seo, J.; Kim, E.K.; Noh, J.H. Iodide management in formamidinium-lead-halide-based perovskite layers for efficient solar cells. Science 2017, 356, 1376-1379. [CrossRef] [PubMed]

8. X Xing, G.; Mathews, N.; Sun, S.; Lim, S.S.; Lam, Y.M.; Grätzel, M.; Mhaisalkar, S.; Sum, T.C. Long-range balanced electron-and hole-transport lengths in organic-inorganic $\mathrm{CH}_{3} \mathrm{NH}_{3} \mathrm{PbI}_{3}$. Science 2013, 342, 344-347. [CrossRef]

9. Kojima, A.; Teshima, K.; Shirai, Y.; Miyasaka, T. Organometal halide perovskites as visible-light sensitizers for photovoltaic cells. J. Am. Chem. Soc. 2009, 131, 6050-6051. [CrossRef]

10. Grätzel, M. The light and shade of perovskite solar cells. Nat. Mater. 2014, 13, 838. [CrossRef]

11. Edri, E.; Kirmayer, S.; Mukhopadhyay, S.; Gartsman, K.; Hodes, G.; Cahen, D. Elucidating the charge carrier separation and working mechanism of $\mathrm{CH}_{3} \mathrm{NH}_{3} \mathrm{PbI}_{3}-\mathrm{xClx}$ perovskite solar cells. Nat. Commun. 2014, 5, 3461. [CrossRef]

12. Shih, Y.-C.; Wang, L.; Hsieh, H.-C.; Lin, K.-F. Enhancing the photocurrent of perovskite solar cells via modification of the $\mathrm{TiO}_{2} / \mathrm{CH}_{3} \mathrm{NH}_{3} \mathrm{PbI}_{3}$ heterojunction interface with amino acid. J. Mater. Chem. A 2015, 3, 9133-9136. [CrossRef]

13. Zhu, Z.; Ma, J.; Wang, Z.; Mu, C.; Fan, Z.; Du, L.; Bai, Y.; Fan, L.; Yan, H.; Phillips, D.L. Efficiency enhancement of perovskite solar cells through fast electron extraction: The role of graphene quantum dots. J. Am. Chem. Soc. 2014, 136, 3760-3763. [CrossRef] [PubMed]

14. Yang, W.S.; Noh, J.H.; Jeon, N.J.; Kim, Y.C.; Ryu, S.; Seo, J.; Seok, S.I. High-performance photovoltaic perovskite layers fabricated through intramolecular exchange. Science 2015, 348, 1234-1237. [CrossRef] [PubMed]

15. Wojciechowski, K.; Saliba, M.; Leijtens, T.; Abate, A.; Snaith, H.J. Sub-150 ${ }^{\circ} \mathrm{C}$ processed meso-superstructured perovskite solar cells with enhanced efficiency. Energy Environ. Sci. 2014, 7, 1142-1147. [CrossRef]

16. Liu, D.; Kelly, T.L. Perovskite solar cells with a planar heterojunction structure prepared using room-temperature solution processing techniques. Nat. Photonics 2014, 8, 133. [CrossRef]

17. Ouyang, D.; Huang, Z.; Choy, W.C. Solution-processed metal oxide nanocrystals as carrier transport layers in organic and perovskite solar cells. Adv. Funct. Mater. 2019, 29, 1804660. [CrossRef]

18. Zhang, T.; Li, H.; Ban, H.; Sun, Q.; Shen, Y.; Wang, M. Efficient CsSnI 3 -based inorganic perovskite solar cells based on a mesoscopic metal oxide framework via incorporating a donor element. J. Mater. Chem. A 2020, 8 , 4118-4124. [CrossRef]

19. Fernandes, S.L.; Véron, A.C.; Neto, N.F.; Nüesch, F.A.; da Silva, J.H.D.; Zaghete, M.A.; Carlos, F.d.O. Nb $2 \mathrm{O}_{5}$ hole blocking layer for hysteresis-free perovskite solar cells. Mater. Lett. 2016, 181, 103-107. [CrossRef]

20. Anaraki, E.H.; Kermanpur, A.; Steier, L.; Domanski, K.; Matsui, T.; Tress, W.; Saliba, M.; Abate, A.; Grätzel, M.; Hagfeldt, A. Highly efficient and stable planar perovskite solar cells by solution-processed tin. Energy Environ. Sci. 2016, 9, 3128-3134. [CrossRef]

21. Jiang, Q.; Zhang, L.; Wang, H.; Yang, X.; Meng, J.; Liu, H.; Yin, Z.; Wu, J.; Zhang, X.; You, J.J.N.E. Enhanced electron extraction using $\mathrm{SnO}_{2}$ for high-efficiency planar-structure $\mathrm{HC}\left(\mathrm{NH}_{2}\right)_{2} \mathrm{PbI}_{3}$-based perovskite solar cells. Nat. Energy 2016, 2, 1-7. [CrossRef]

22. Ozaki, M.; Ishikura, Y.; Truong, M.A.; Liu, J.; Okada, I.; Tanabe, T.; Sekimoto, S.; Ohtsuki, T.; Murata, Y.; Murdey, R. Iodine-rich mixed composition perovskites optimised for tin (iv) oxide transport layers: The influence of halide ion ratio, annealing time, and ambient air aging on solar cell performance. J. Mater. Chem. A 2019, 7, 16947-16953. [CrossRef]

23. Zhang, W.; Wan, L.; Li, X.; Wu, Y.; Fu, S.; Fang, J. A dopant-free polyelectrolyte hole-transport layer for high efficiency and stable planar perovskite solar cells. J. Mater. Chem. A 2019, 7, 18898-18905. [CrossRef]

24. Zhao, J.; Tavakoli, R.; Tavakoli, M.M. Synergistic interface and compositional engineering of inverted perovskite solar cells enables highly efficient and stable photovoltaic devices. Chem. Commun. 2019, 55, 9196-9199. [CrossRef] [PubMed] 
25. Tsarev, S.; Yakushchenko, I.K.; Luchkin, S.Y.; Kuznetsov, P.M.; Timerbulatov, R.S.; Dremova, N.N.; Frolova, L.A.; Stevenson, K.J.; Troshin, P.A. A new polytriarylamine derivative for dopant-free high-efficiency perovskite solar cells. Sustain. Energy Fuels 2019, 3, 2627-2632. [CrossRef]

26. Mali, S.S.; Kim, H.; Kim, H.H.; Shim, S.E.; Hong, C.K. Nanoporous p-type $\mathrm{NiO}_{\mathrm{x}}$ electrode for pin inverted perovskite solar cell toward air stability. Mater. Today 2018, 21, 483-500. [CrossRef]

27. Cao, J.; Wu, B.; Chen, R.; Wu, Y.; Hui, Y.; Mao, B.W.; Zheng, N. Efficient, Hysteresis-Free, and Stable Perovskite Solar Cells with ZnO as Electron-Transport Layer: Effect of Surface Passivation. Adv. Mater. 2018, 30, 1705596. [CrossRef]

28. Yu, H.; Yeom, H.I.; Lee, J.W.; Lee, K.; Hwang, D.; Yun, J.; Ryu, J.; Lee, J.; Bae, S.; Kim, S.K. Superfast Room-Temperature Activation of $\mathrm{SnO}_{2}$ Thin Films via Atmospheric Plasma Oxidation and their Application in Planar Perovskite Photovoltaics. Adv. Mater. 2018, 30, 1704825. [CrossRef]

29. Scheideler, W.J.; Rolston, N.; Zhao, O.; Zhang, J.; Dauskardt, R.H. Rapid Aqueous Spray Fabrication of Robust $\mathrm{NiO}_{\mathrm{x}}$ : A Simple and Scalable Platform for Efficient Perovskite Solar Cells. Adv. Energy. 2019, 9, 1803600. [CrossRef]

30. Abzieher, T.; Moghadamzadeh, S.; Schackmar, F.; Eggers, H.; Sutterlüti, F.; Farooq, A.; Kojda, D.; Habicht, K.; Schmager, R.; Mertens, A. Electron-Beam-Evaporated Nickel Oxide Hole Transport Layers for Perovskite-Based Photovoltaics. Adv. Energy Mater. 2019, 9, 1802995. [CrossRef]

31. Lu, G.; Wang, X.; Du, J.; Zhang, M.; Gao, Y.; Liu, Y.; Ma, J.; Lin, Z. Enhancing Perovskite Solar Cell Performance through Surface Engineering of Metal Oxide Electron-Transporting Layer. Coatings 2020, 10, 46. [CrossRef]

32. Hossain, M.I.; Yumnam, N.; Qarony, W.; Salleo, A.; Wagner, V.; Knipp, D.; Tsang, Y.H. Non-resonant metal-oxide metasurfaces for efficient perovskite solar cells. Sol. Energy 2020, 198, 570-577. [CrossRef]

33. Chiu, C.; Pei, Z.; Chang, S.; Chang, S.; Chang, S.-J. Effect of oxygen partial pressure on electrical characteristics of amorphous indium gallium zinc oxide thin-film transistors fabricated by thermal annealing. Vacuum 2011, 86, 246-249. [CrossRef]

34. Chen, W.-T.; Lo, S.-Y.; Kao, S.-C.; Zan, H.-W.; Tsai, C.-C.; Lin, J.-H.; Fang, C.-H.; Lee, C.-C. Oxygen-dependent instability and annealing/passivation effects in amorphous In-Ga-Zn-O thin-film transistors. IEEE Electron. Device Lett. 2011, 32, 1552-1554. [CrossRef]

35. Park, K.; Choi, J.-Y.; Lee, H.-J.; Kwon, J.-Y.; Kim, H. Thin film transistor using amorphous InGaZnO films as both channel and source/drain electrodes. Jpn. J. Appl. Phys. 2011, 50, 096504. [CrossRef]

36. Park, Y.J.; Song, A.; Walker, B.; Seo, J.H.; Chung, K.B. Hybrid ZnON-Organic Light Emitting Transistors with Low Threshold Voltage< 5 V. Adv. Opt. Mater. 2019, 7, 1801290.

37. Park, J.; Kim, Y.S.; Ok, K.-C.; Park, Y.C.; Kim, H.Y.; Park, J.-S.; Kim, H.-S. A study on the electron transport properties of $\mathrm{ZnON}$ semiconductors with respect to the relative anion content. Sci. Rep. 2016, 6, 24787. [CrossRef]

38. Tseng, Z.-L.; Chiang, C.-H.; Wu, C.-G. Surface engineering of ZnO thin film for high efficiency planar perovskite solar cells. Sci. Rep. 2015, 5, 13211. [CrossRef]

39. Kim, J.; Kim, G.; Kim, T.K.; Kwon, S.; Back, H.; Lee, J.; Lee, S.H.; Kang, H.; Lee, K. Efficient planar-heterojunction perovskite solar cells achieved via interfacial modification of a sol-gel $\mathrm{ZnO}$ electron. J. Mater. Chem. A 2014, 2, 17291-17296. [CrossRef]

40. Paine, D.C.; Yaglioglu, B.; Beiley, Z.; Lee, S. Amorphous IZO-based transparent thin film transistors. Thin Solid Films 2008, 516, 5894-5898. [CrossRef]

41. Wang, L.; Liu, F.; Cai, X.; Ma, T.; Jiang, C. Indium Zinc Oxide Electron Transport Layer for High-Performance Planar Perovskite Solar Cells. J. Phy. Chem. C 2018, 122, 28491-28496. [CrossRef]

42. Park, H.-W.; Song, A.; Kwon, S.; Choi, D.; Kim, Y.; Jun, B.-H.; Kim, H.-K.; Chung, K.-B. Enhancing the performance of tungsten doped InZnO thin film transistors via sequential ambient annealing. Appl. Phys. Lett. 2018, 112, 123501. [CrossRef]

43. Park, H.-W.; Song, A.; Kwon, S.; Du Ahn, B.; Chung, K.-B. Improvement of device performance and instability of tungsten-doped InZnO thin-film transistor with respect to doping concentration. Appl. Phys. Express 2016, 9, 111101. [CrossRef]

44. Park, H.-W.; Song, A.; Choi, D.; Kim, H.-J.; Kwon, J.-Y.; Chung, K.-B. Enhancement of the device performance and the stability with a homojunction-structured tungsten indium zinc oxide thin film transistor. Sci. Rep. 2017, 7, 11634. [CrossRef] 
45. Zhou, Z.; Xu, J.; Xiao, L.; Chen, J.; Tan, Z.a.; Yao, J.; Dai, S. Efficient planar perovskite solar cells prepared via a low-pressure vapor-assisted solution process with fullerene/ $\mathrm{TiO}_{2}$ as an electron collection bilayer. RSC Adv. 2016, 6, 78585-78594. [CrossRef]

46. Ke, W.; Zhao, D.; Grice, C.R.; Cimaroli, A.J.; Ge, J.; Tao, H.; Lei, H.; Fang, G.; Yan, Y. Efficient planar perovskite solar cells using room-temperature vacuum-processed $\mathrm{C}_{60}$ electron selective layers. J. Mater. Chem. A 2015, 3, 17971-17976. [CrossRef]

47. Ke, W.; Zhao, D.; Xiao, C.; Wang, C.; Cimaroli, A.J.; Grice, C.R.; Yang, M.; Li, Z.; Jiang, C.-S.; Al-Jassim, M. Cooperative tin oxide fullerene electron selective layers for high-performance planar perovskite solar cells. J. Mater. Chem. A 2016, 4, 14276-14283. [CrossRef]

48. Mori, T.; Kato, K. Photovoltaic properties of organic thin-film solar cell using various exciton-diffusion blocking materials. J. Photopolym. Sci. Technol. 2007, 20, 61-66. [CrossRef]

49. Li, G.; Shrotriya, V.; Huang, J.; Yao, Y.; Moriarty, T.; Emery, K.; Yang, Y. High-efficiency solution processable polymer photovoltaic cells by self-organization of polymer blends. In Materials for Sustainable Energy: A Collection of Peer-Reviewed Research and Review Articles from Nature Publishing Group; World Scientific: Singapore, 2011; pp. 80-84.

50. Yang, W.; Zhong, D.; Shi, M.; Qu, S.; Chen, H. Toward Highly Thermal Stable Perovskite Solar Cells by Rational Design of Interfacial Layer. iScience 2019, 22, 534-543. [CrossRef]

51. Jiang, X.; Wang, F.; Wei, Q.; Li, H.; Shang, Y.; Zhou, W.; Wang, C.; Cheng, P.; Chen, Q.; Chen, L. Ultra-high open-circuit voltage of tin perovskite solar cells via an electron transporting layer design. Nat. Commun. 2020, 11, 1-7. [CrossRef]

52. Mahmood, K.; Sarwar, S.; Mehran, M.T. Current status of electron transport layers in perovskite solar cells: Materials and properties. RSC Adv. 2017, 7, 17044-17062. [CrossRef]

53. Shao, Y.; Xiao, Z.; Bi, C.; Yuan, Y.; Huang, J. Origin and elimination of photocurrent hysteresis by fullerene passivation in $\mathrm{CH}_{3} \mathrm{NH}_{3} \mathrm{PbI}_{3}$ planar heterojunction solar cells. Nat. Commun. 2014, 5, 1-7. [CrossRef] [PubMed]

54. Wang, Q.; Shao, Y.; Dong, Q.; Xiao, Z.; Yuan, Y.; Huang, J. Large fill-factor bilayer iodine perovskite solar cells fabricated by a low-temperature solution-process. Energy Environ. Sci. 2014, 7, 2359-2365. [CrossRef]

55. Xu, J.; Buin, A.; Ip, A.H.; Li, W.; Voznyy, O.; Comin, R.; Yuan, M.; Jeon, S.; Ning, Z.; McDowell, J.J. Perovskite-fullerene hybrid materials suppress hysteresis in planar diodes. Nat. Commun. 2015, 6, 1-8. [CrossRef] [PubMed]

56. Park, J.; Kim, Y.S.; Kim, J.H.; Park, K.; Park, Y.C.; Kim, H.-S. The effects of active layer thickness and annealing conditions on the electrical performance of ZnON thin-film transistors. J. Alloys Compd. 2016, 688, 666-671. [CrossRef]

57. Park, H.-W.; Park, K.; Kwon, J.-Y.; Choi, D.; Chung, K.-B. Effect of active layer thickness on device performance of tungsten-doped InZnO thin-film transistor. IEEE Trans. Electron Devices 2016, 64, 159-163. [CrossRef]

58. Shao, Y.; Yuan, Y.; Huang, J. Correlation of energy disorder and open-circuit voltage in hybrid perovskite solar cells. Nat. Energy 2016, 1, 15001. [CrossRef]

59. Zhang, M.-D.; Zhao, D.-X.; Chen, L.; Pan, N.; Huang, C.-Y.; Cao, H.; Chen, M.-D. Structure-performance relationship on the asymmetric methoxy substituents of spiro-OMeTAD for perovskite solar cells. Solar Energy Mater. Solar Cells 2018, 176, 318-323. [CrossRef]

60. Zhu, Q.; Bao, X.; Yu, J.; Zhu, D.; Qiu, M.; Yang, R.; Dong, L. Compact layer free perovskite solar cells with a high-mobility hole-transporting layer. ACS Appl. Mater. Interfaces 2016, 8, 2652-2657. [CrossRef]

61. Futsuhara, M.; Yoshioka, K.; Takai, O. Optical properties of zinc oxynitride thin films. Thin Solid Films 1998, 317, 322-325. [CrossRef]

62. Tvingstedt, K.; Malinkiewicz, O.; Baumann, A.; Deibel, C.; Snaith, H.J.; Dyakonov, V.; Bolink, H.J. Radiative efficiency of lead iodide based perovskite solar cells. Sci. Rep. 2014, 4, 6071. [CrossRef]

63. Lin, P.-Y.; Wu, T.; Ahmadi, M.; Liu, L.; Haacke, S.; Guo, T.-F.; Hu, B. Simultaneously enhancing dissociation and suppressing recombination in perovskite solar cells. Nano Energy 2017, 36, 95-101. [CrossRef]

64. Gelmetti, I.; Montcada, N.F.; Pérez-Rodríguez, A.; Barrena, E.; Ocal, C.; García-Benito, I.; Molina-Ontoria, A.; Martín, N.; Vidal-Ferran, A.; Palomares, E. Energy alignment and recombination in perovskite solar cells: Weighted influence on the open circuit voltage. Energy Environ. Sci. 2019, 12, 1309-1316. [CrossRef] 
65. Sherkar, T.S.; Momblona, C.; Gil-Escrig, L.N.; Ávila, J.; Sessolo, M.; Bolink, H.J.; Koster, L.J.A. Recombination in perovskite solar cells: Significance of grain boundaries, interface traps, and defect ions. ACS Energy Lett. 2017, 2, 1214-1222. [CrossRef] [PubMed]

66. Liu, Z.; Chen, Q.; Hong, Z.; Zhou, H.; Xu, X.; De Marco, N.; Sun, P.; Zhao, Z.; Cheng, Y.-B.; Yang, Y. Low-temperature $\mathrm{TiO}$ x compact layer for planar heterojunction perovskite solar cells. ACS Appl. Mater. Interfaces 2016, 8, 11076-11083. [CrossRef] [PubMed]

67. Rao, H.S.; Chen, B.X.; Li, W.G.; Xu, Y.F.; Chen, H.Y.; Kuang, D.B.; Su, C.Y. Improving the extraction of photogenerated electrons with $\mathrm{SnO} 2$ nanocolloids for efficient planar perovskite solar cells. Adv. Funct. Mater. 2015, 25, 7200-7207. [CrossRef]

68. Shi, J.; Xu, X.; Li, D.; Meng, Q. Interfaces in perovskite solar cells. Small 2015, 11, 2472-2486. [CrossRef] [PubMed]

69. Berhe, T.A.; Su, W.-N.; Chen, C.-H.; Pan, C.-J.; Cheng, J.-H.; Chen, H.-M.; Tsai, M.-C.; Chen, L.-Y.; Dubale, A.A.; Hwang, B.-J. Organometal halide perovskite solar cells: Degradation and stability. Energy Environ. Sci. 2016, 9, 323-356. [CrossRef]

70. Jung, E.H.; Jeon, N.J.; Park, E.Y.; Moon, C.S.; Shin, T.J.; Yang, T.-Y.; Noh, J.H.; Seo, J. Efficient, stable and scalable perovskite solar cells using poly (3-hexylthiophene). Nature 2019, 567, 511-515. [CrossRef] [PubMed]

71. Yang, G.; Zhang, H.; Li, G.; Fang, G. Stabilizer-assisted growth of formamdinium-based perovskites for highly efficient and stable planar solar cells with over 22\% efficiency. Nano Energy 2019, 63, 103835. [CrossRef]

72. Hu, M.; Bi, C.; Yuan, Y.; Bai, Y.; Huang, J. Stabilized wide bandgap MAPbBrxI3-x perovskite by enhanced grain size and improved crystallinity. Adv. Sci. 2016, 3, 1500301. [CrossRef] [PubMed]

73. Kyaw, A.K.K.; Wang, D.H.; Gupta, V.; Zhang, J.; Chand, S.; Bazan, G.C.; Heeger, A.J. Efficient solution-processed small-molecule solar cells with inverted structure. Adv. Mater. 2013, 25, 2397-2402. [CrossRef] [PubMed]

74. Ko, S.J.; Choi, H.; Hoang, Q.V.; Song, C.E.; Morin, P.O.; Heo, J.; Leclerc, M.; Yoon, S.C.; Woo, H.Y.; Shin, W.S. Modeling and implementation of tandem polymer solar cells using wide-bandgap front cells. Carbon Energy 2020, 2, 131-142. [CrossRef] 